\title{
Yam Protection: I: Seed-Piece Treatment with Fungicide $^{1}$
}

\author{
J. S. Mignucci, P. R. Hepperly, H. Vélez, and R. Torres ${ }^{2}$
}

\begin{abstract}
Preplant fungicide baths were tested on yam (Dioscorea rotundata Poir cv. Habanero) seed pieces (114-g sections) from sound tubers to determine their effect on emergence and yield of yams. Field plots were free of damaging populations of parasitic nematodes and had not been previously planted with yams. Yam seed pieces treated with captan or captan plus thiabendazole or captan plus benomyl increased field emergence $(95,96$ and $91 \%$, respectively) over that of nontreated controls $(52 \%)$. Early emergence (5 weeks after planting) was greater for captan plus thiabendazole $(24 \%)$ than for captan plus benomyl $(1 \%)$, captan alone $(2 \%)$, or the nontreated control $(1 \%)$. Final stand counts ( 9 weeks after planting) were not statistically different among the fungicide treatments $(91-96 \%)$. These counts were highly correlated with total tuber yield $\left(r=0.84^{* *}\right)$, total number of harvested tubers $\left(r=0.77^{* *}\right)$, and mean tuber weight $\left(r=0.74^{* *}\right)$. Plants from nontreated seed pieces produced a higher number of tubers per plant (1.64) compared with those from fungicide treated seed-pieces $(1.16-1.20)$. Yield losses in nontreated seed pieces $(48 \%)$ were related to losses in mean tuber weight $(37 \%)$ and in total number of tubers $(20 \%)$ per area when compared to the treated seed pieces. Greatest per plant and total yield and greatest tuber weight were found for the captan plus thiabendazole treatment, compared with captan alone or captan plus benomyl. Early and greater emergence of yam seed pieces appear to be important determinants of yield and tuber size in Habanero yams. In this experiment, even with good seed pieces and in a well-prepared seedbed, yam emergence and yield were diminished by one-half without fungicide treatment.
\end{abstract}

\section{INTRODUCTION}

Edible yams (Dioscorea spp.) are long season (6 to 12 months) tropical vines which are cultivated for their starchy tubers (15). Nutritionally, yams are most important because of their content of complex carbohydrates (22). Compared with other root crops, yams have higher protein (up to $13 \%$ in some cases) and a better balanced amino acids composition (23). Although yams are grown throughout many tropical and subtropical areas (15), they are most important as a food crop in West Africa and in the Caribbean Basin. Of the 60 or more species of yams, 10 are considered to be cultivated; four of these are commercially important. The high yield and harvest index of yams make them ideal candidates for increasing food production in the tropics. Currently, yams are produced in labor intensive systems under traditional cultivation which could be greatly improved.

In Puerto Rico, yams are important in the humid hills where farmers

${ }^{1}$ Manuscript submitted to the Editorial Board May 9, 1983.

${ }^{2}$ Associate Plant Pathologist, Assistant Plant Pathologist, Graduate Student and Research Assistant, respectively, Dept. of Crop Protection Agricultural Experiment Station, University of Puerto Rico, Mayagüez Campus 00708. 
grow them in small fields usually of 1 to 3 hectares (16). Dioscorea alata $c v$. Florido and $D$. rotundata cv. Habanero are the only yams of economic importance on the Island $(9,10,16)$. In 1979-80, yam production reached 340,000 cwt with a farm value of $\$ 7.6$ million (7). In recent years, the price of yams has risen steadily while yield and production area have remained practically constant. Since the domestic production does not satisfy local demand and there is considerable export demand for the crop, increasing per area yield is economically promising.

As in many small-farmer crops of the tropics, yam pest control has received little attention from farmers and researchers. A limited amount of scientific information suggests that substantial yam losses are caused by nematodes (1) and other pests (16). Many yam losses occur by pests directly attacking yams stored for marketing or for seed $(4,16,17)$. Nwankiti and Arene (17) consider yam tuber rots as the most serious of all disease losses in Nigeria. Successful storage of yams past one month depends on proper curing to stimulate the healing of harvest wounds which otherwise stimulate rot incited by fungi and bacteria (2).

Storage rots of yams have been divided into two categories on the basis of the causal agent and associated symptoms. Nematodes (Pratylenchus coffeae and Scuttellonema bradys) are often associated with dry storage rot of yams although fungi such as Fusarium and Penicillium spp. can also cause dry rot $(1,17)$. Wet rot is mostly associated with decay fungi, particularly Botryodiplodia and Fusarium, and other species, although bacteria alone or in combination with fungi and nematodes may produce wet rot symptoms (17). In Puerto Rico, D. alata cv. Florido appears to be more resistant to losses by both dry and wet rot caused by fungi than D. rotundata $\mathrm{cv}$. Habanero. ${ }^{3}$ Storage losses of yams have been observed to be above $50 \%$ on local farms. ${ }^{3}$ In Trinidad, storage losses of 7 to $23 \%$ were found after 4 months storage for $D$. alata cultivars (11).

Burton (4), Ogundana (18), and Thompson et al. (24) have worked on the chemical control of wet storage rot of yams. Burton found sodium $\mathrm{O}$ phenylphenate and 2,5-dichloro-4-nitroaniline alone and in combination gave partial control of wet rot. Ogundana (18) and Thompson et al. (24) found that thiabendazole at $1,000 \mathrm{p} / \mathrm{m}$ gave excellent control of most common fungi causing wet rot of yams. Coursey (6) cited lime, borax, and Bordeaux mixture as traditional chemical control measures to arrest yam decays in storage. In Puerto Rico few if any crop protection measures are normally used by farmers to prevent yam tuber decay $(9,10,16)$.

Although yam rot can occur before and during storage, field rot of yam tubers has received little attention compared to those of stored yams. In

${ }^{3}$ J. S. Mignucci, unpublished. 
other root crops, such as potatoes, tuber rots before and shortly after crop emergence can cause substantial crop losses $(3,13)$. With this fact in mind, we have reported on losses on seed pieces by fungal decay in the field after planting, its effect on yam yields, and its control by preplant fungicide baths.

\section{MATERIALS AND METHODS}

On December 15, 1980, yam tubers (Dioscorea rotundata cv. Habanero) were harvested and stored at the Corozal Substation of the University of Puerto Rico Agricultural Experiment Station. Three months later, sound tubers of good appearance were selected and cut into sections (approximately $114 \mathrm{~g}$ each), treated for one hour in fungicide baths or with water. Fungicide baths at $27^{\circ} \mathrm{C}$ were stirred every 10 minutes for 1 hour. Afterwards, baths were drained and seed pieces were placed in a shade house at $35^{\circ} \mathrm{C}$ and $80 \% \mathrm{RH}$ for 2 days to allow wound healing. Watertreated seed pieces served as experimental controls. Seed pieces were planted 28 March 1981 at the Alzamora Farm of the College of Agriculture, in Mayagüez. The experimental site consisted of a silty-clay Ultisol of $\mathrm{pH} 5.0$ typical of many yam production areas in Puerto Rico. In three previous seasons the field had been cropped to soybeans. Samples of soil from the site were analyzed for pathogenic nematodes before planting and after harvesting.

Fungicide treatments were based on commercial formulations of captan alone (N-(trichloromethylthio)-4-cyclohexene-1,2-dicarboxide, Orthocide $4 \mathrm{~F}){ }^{4}$ captan plus thiabendazole (2-(4-thiazolyl) benzimidazole; Orthocide (plus $10 \%$ captan and $0.5 \%$ thiabendazole) and captan plus benomyl [methyl (1-butylcarbamoyl)-2-benzimidazole carbamate, DPX$115 \mathrm{~B},(50 \%$ captan and $10 \%$ benomyl)]. For all fungicide baths $2,000 \mathrm{p} /$ m captan was used.

A complete block design with four replications of 25 seed pieces each was used for the experiment. Seed pieces were hand planted $8 \mathrm{~cm}$ deep every $20 \mathrm{~cm}$ on $50 \mathrm{~cm}$ high banks with $67 \mathrm{~cm}$ between adjacent banks. Emergence was recorded 5, 6, 7, 8, and 9 weeks after planting. Yams were harvested at maturity 14 January, 1981. Tubers per plant were counted and weighed. Data was analyzed for variance and treatment means were compared with Fischer's Least Significant Difference (FLSD). Per plot measurements were used to determine simple linear correlations between parameters.

\footnotetext{
${ }^{4}$ Trade names of pesticides are solely mentioned to provide specific information not to endorse specific products. Mention of a trade name does not constitute a warranty of the product by the University of Puerto Rico nor does it imply its endorsement over other products not mentioned.
} 


\section{RESULTS AND DISCUSSION}

Fungicide seed piece treatments were highly effective in preventing emergence losses (table 1). There was 91 to $96 \%$ emergence in fungicide treated seed pieces, compared with $52 \%$ for the nontreated control. Early emergence (5 weeks after planting) was higher for captan plus thiabendazole than for pieces treated with captan plus benomyl, captan alone, or nontreated seed pieces $(12 \%)$. This fact suggests that the superior emergence of the captan plus thiabendazole treatment compared with that of captan alone may be related to stimulation of seed piece metabolism by thiabendazole. Elstner et al. (8) found that thiabendazole

TABLE 1.-Fungicide treatments of yam (Dioscorea rotundata $c v$. Habanero) seed-pieces and their influence on the rate and frequency of yam field emergence in Mayagüez, Puerto Rico

\begin{tabular}{|c|c|c|c|c|c|}
\hline \multirow{3}{*}{ Treatment } & \multicolumn{5}{|c|}{ Percentage emergence } \\
\hline & \multicolumn{5}{|c|}{ Weeks after planting } \\
\hline & 5 & 6 & 7 & 8 & 9 \\
\hline $\begin{array}{l}\text { Captan + thiabendazole, Ortho- } \\
\text { cide Plus }(10 \% \text { captan and } \\
0.5 \% \text { thiabendazole }\end{array}$ & $24^{* * 2}$ & $54^{* *}$ & $73^{* *}$ & $73^{* * *}$ & $96^{* *}$ \\
\hline $\begin{array}{l}\text { Captan, Orthocide } 4 \mathrm{~F} \text { ( } 36 \% \text { cap- } \\
\text { tan) }\end{array}$ & 2 & $23^{* *}$ & $71^{* *}$ & $85^{* *}$ & $95^{* *}$ \\
\hline $\begin{array}{l}\text { Captan + benomyl, DPX 115B } \\
\quad(50 \% \text { captan and 10\% benomyl) }\end{array}$ & 1 & $16^{* *}$ & $53^{* *}$ & $72^{* *}$ & $91^{* *}$ \\
\hline Nontreated (check) & 1 & 2 & 10 & 36 & 52 \\
\hline
\end{tabular}

${ }^{1}$ Seed pieces were placed in fungicide baths for 1 hour at $27^{\circ} \mathrm{C}$. All fungicide baths used $2,000 \mathrm{p} / \mathrm{m}$ captan.

${ }^{2}$ Highly significant $(\mathrm{P}=0.01$ ) difference between the treatment and the control (Fischer's Least Significant Difference).

increased respiration, lipid peroxidation, and ethane evolution of wounded potatoes. Since the activity was found in intact tissues but not in homogenates, the authors considered that thiabendazole had hormonelike action. Benzimidazole fungicides are chemically similar to cytokinin plant hormones and have been used extensively in detached leaf cultures to retard tissue senescence $(12,14)$. As well as retarding senescence $(19$, 20,21), cytokinins strongly promote bud development, seed germination, and protein synthesis.

From this experiment it appears that even when good sound tubers are used and optimum seedbed conditions exist, seed piece decay can reduce emergence by almost one-half. Damaging populations of pathogenic nematodes were not associated with the field site or the seed tubers, nor were they detected in the subsequent harvest. Seed piece losses in this experiment were associated with soil or tuber-borne fungi, or both. 
Yield per plot from fungicide treated seed pieces doubled those of the nontreated seed pieces (table 2). Seedling emergence was highly correlated with tuber number $\left(r=0.77^{* *}\right)$, yield/plot $\left(r=0.84^{* *}\right)$, and mean tuber weight $\left(r=0.74^{* *}\right)$. The number of tubers was not highly correlated with mean tuber weight ( $r=0.45 \mathrm{NS}$ ) but was highly correlated with yield $\left(r=0.75^{* *}\right)$. Mean tuber weight was also highly correlated with total tuber yield $\left(r=0.92^{* *}\right)$. Yields from fungicide treated seed pieces varied from 39,000 to $48,000 \mathrm{~kg} / \mathrm{ha}$, with the highest yield coming from the captan plus thiabendazole treatment which had shown better earlier emergence (tables 1 and 2).

TABLE 2.-The effect of yam (Dioscorea rotundata $c v$. Habanero) seed piece fungicide treatment on the yield of yams and its components in Mayagüez, Puerto Rico

\begin{tabular}{|c|c|c|c|c|c|}
\hline Treatment $^{1}$ & $\begin{array}{l}\text { Total } \\
\text { yield/ } \\
\text { plot }\end{array}$ & Tuber & $\begin{array}{l}\text { Plant } \\
\text { yield }\end{array}$ & $\begin{array}{c}\text { Tubers/ } \\
\text { plant }\end{array}$ & $\begin{array}{l}\text { Tuber } \\
\text { weight }\end{array}$ \\
\hline & $\mathrm{g}$ & no. & $\mathrm{kg}$ & no. & $\mathrm{g}$ \\
\hline $\begin{array}{l}\text { Captan plus thiabendazole, } \\
\text { Orthocide plus ( } 10 \% \\
\text { captan and } 0.5 \% \text { thia- } \\
\text { bendazole) }\end{array}$ & $27.0^{2} \mathrm{~B}^{3}$ & $28.5 \mathrm{a}$ & $1.1 \mathrm{a}$ & $1.20 \mathrm{~A}$ & $942 \mathrm{aA}$ \\
\hline $\begin{array}{l}\text { Captan, Orthocide } 4 \mathrm{~F} \text { ( } 36 \% \\
\text { captan) }\end{array}$ & $22.0 \mathrm{~B}$ & $28.5 \mathrm{a}$ & $0.9 \mathrm{a}$ & $1.16 \mathrm{~A}$ & $770 \mathrm{bAB}$ \\
\hline $\begin{array}{l}\text { Captan plus benomyl } \\
\text { DPX-115B ( } 50 \% \text { captan } \\
\text { and } 10 \% \text { benomyl) }\end{array}$ & $22.5 \mathrm{~B}$ & $26.3 \mathrm{a}$ & $1.0 \mathrm{a}$ & $1.20 \mathrm{~A}$ & $858 \mathrm{abA}$ \\
\hline Nontreated (check) & $12.6 \mathrm{C}$ & $22.5 \mathrm{~b}$ & $1.0 \mathrm{a}$ & 1.64 B & $560 \mathrm{cB}$ \\
\hline
\end{tabular}

${ }^{1}$ All fungicide baths contained $2,000 \mathrm{p} / \mathrm{m}$ captan for one hour at $27^{\circ} \mathrm{C}$.

${ }^{2}$ Means based on four replications of 25 seed pieces each.

${ }^{3}$ Values followed by a common lower or upper case letter do not differ statistically at $\mathrm{P}$ $=0.05$ and $P=0.01$, respectively, based on Fischer's Least Significant Difference.

Non-treated yam seed pieces showed an increase in the mean number of tubers per plant (1.6) compared to those from fungicide treatments $(1,2)$. Total number of tubers and mean tuber weight per area were less for nontreated seed pieces than for any of the fungicide treated seed pieces. These data suggest that although nontreated yams reacted to stand losses by initiating more tubers per plant, yield compensation did not occur, since per plant yield was not increased in comparison to that obtained from the fungicide-treated yam pieces. In this experiment yield/ plant was not different among the treatments (table 2). Possibly yams are less able to compensate on the basis of their longer period for plant emergence (9 weeks) compared with that of many seed crops where germination occurs a few days after planting. When germination is rapid, the exposure period to soil borne pathogens is short. Emergence of yams 
from seed pieces can require 1 to 2 months, rendering them extremely vulnerable to soil pathogens over an extended period of time. Susceptibility to decay is also increased by wounded surfaces as those which are provided by the cutting of the seed piece. Considering this long exposure to soil- and tuber-borne pathogens and the presence of wounds, it may be likely that seed piece infections become chronic in the emerging yam plant, and thus increased yield on a per plant basis is limited.

Because of reduced labor costs, less decay, and less mechanical transmission of pathogens, the use of small whole potato seed tubers has gained popularity in seed production areas (5). Specialized production and use of small yam tubers for seed may help promote healthier and more vigorous yam seedlings and possibly reduce the need to use pesticides. Alternatives such as this should be explored in further studies.

On the basis of this work, a failure to treat yam seed pieces from sound tubers with appropriate fungicides will probably result in significant economic losses to farmers. Cost of yam seed tubers or seed pieces is a significant production expense considering that, compared with most seed crops, a tremendous mass of tubers is planted on a per area basis. If 10,000 to 20,000 plants per hectare are desired, and $114 \mathrm{~g}$-seed pieces at a cost of $\$ 0.80$ to $\$ 1.00$ per kg are used, $\$ 800$ to $\$ 2,000$ per hectare will be invested in seed alone. Given a $50 \%$ mortality of non-treated seed pieces, direct losses could amount from $\$ 400$ to $\$ 1,000$ per hectare. Besides the direct loss of seed pieces, the biggest loss is the indirect loss caused by the reduction in total yield. In normal practice farmers use seed pieces or whole tubers, or both, which range from 225 to $900 \mathrm{~g}$ in most cases, considerably larger than those used in this experiment (115 g). Therefore, at the farm level, yam losses are probably greater than what we have calculated. Fungicide treatment of seed pieces is a promising practice for increasing yam production in Puerto Rico with a modest capital outlay.

\section{RESUMEN}

Pedazos de $115 \mathrm{~g}$ de ñame Habanero (Dioscorea rotundata Poir) de alta calidad se trataron por una hora con fungicidas, 48 horas antes de sembrarlos para determinar el efecto sobre el brote y el rendimiento. Se escogió un predio experimental que no había estado sembrado de ñames previamente y estaba libre de nematodos parásitos del ñame. Se registró, 91,95 y $96 \%$ de brote en los pedazos tratados con captan + benomyl, captan, y captan + thiabendazole, respectivamente, comparado con $52 \%$ en los que no se trataron con fungicida (testigo). El brote temprano (5 semanas después de la siembra) fue mayor en los pedazos tratados con captan + thiabendazole $(24 \%)$ que en los tratados con captan + benomyl 
$(1 \%)$, con captan $(2 \%)$ o el testigo $(1 \%)$. A las 9 semanas, los tratamientos con fungicidas no fueron diferentes significativamente en el porcentaje de pedazos que brotaron (91-96\%). Se determinaron correlaciones positivas entre el porcentaje de pedazos que brotaron y el rendimiento $\left(r=0.77^{\star *}\right)$; el número total de tubérculos cosechados $\left(r=0.84^{* *}\right)$ y el peso medio de los tubérculos $\left(r=0.74^{* *}\right)$. El testigo produjo más tubérculos por planta (1.64) que los tratados con fungicidas (1.16-1.20). Las pérdidas en el rendimiento del testigo (48\%) estuvieron asociadas con las pérdidas en el peso por tubérculo $(37 \%)$ y con el total producido por área $(20 \%)$. Se registró un mayor rendimiento tanto por planta como por área y por tubérculo en los que se trataron con captan + thiabendazole que con captan o captan + benomyl. Los factores que determinan la producción total y el tamaño de los tubérculos son el brote más temprano y el brote de un número mayor de pedazos. En este estudio aun cuando se seleccionaron tubérculos de alta calidad y se sembraron en condiciones óptimas, el brote y el rendimiento se redujo casi a la mitad cuando los pedazos no se trataron con un fungicida antes de sembrarlos.

\section{LITERATURE CITED}

1. Acosta, N. and Ayala, A., 1973. Pathogenicity of Pratylenchus coffeae, Scutellonema bradys, Meloidogyne incognita, and Rotylenchulus reniformis on Dioscorea rotundata. J. Nematol. 7: 1-5.

2. Been, B. O., Thompson, A. K., and Perkins, C. 1974. Effects of curing on storage of yams. Proc. Caribb. Food Crops Soc. 12: 38-42.

3. Boyd, A. E. W., 1975. Fungicides for potato tubers. Proc. 8th British Insecticide and Fungicide Conf. 3: 1035-044.

4. Burton, C. L., 1970. Diseases of tropical vegetables on the Chicago market. Trop. Agric. Trinidad 47: 303-13.

5. Burton, W. G., 1966. The Potato. H. Veenman and N. V. Zonen, Wageningen, Holland.

6. Coursey, D. G., 1967. Yams. Longmans, London.

7. Department of Agriculture, 1980. Facts and Figures on Puerto Rico's Agriculture, 19791980. Office of Agricultural Statistics. Santurce, P.R.

8. Elstner, E. F., Niehuss, M. and Pils, I., 1981. Stimulation of wound reactions in potato tubers by thiabendazole, Z. Naturforsch. 36(c): 115-21.

9. Estación Experimental Agricola, 1976. Conjunto tecnológico para la producción de cosechas farináceas, Publ. 101. Esta. Agric. Univ. P.R. Exp.

10. González Villafañe, E., Espinet, G. R. and Troche-Ducot, J. C., 1980. Análisis económico de la producción de ñames en Puerto Rico. Publ. 132 Esta. Exp. Agríc. Univ. P.R.

11. Gooding, H. J., 1960. West Indian Dioscorea alata cultivars. Trop. Agric. 37(1): 11-30.

12. Hooker, A. L. and Yarwood, C. E., 1966. Culture of Puccinia sorghi on detached leaves of corn and Oxalis corniculata, Phytopathology 56: 536-39.

13. Hooker, W. J. (Ed), 1981. Compendium of Potato Diseases. Am. Phytopathol. Soc., St. Paul, MN.

14. Liu, Lii-Jang, 1982. Culture of Puccinia melanocephala on detached leaves and uprights of sugarcane in Puerto Rico. J. Agric. Univ. P.R. 66(3): 168-76. 
15. Martin, F. W., 1972. Yam Production Methods. Prod. Res. Rep. 147. USDA, US Govt. Printing Of., Washington, D. C.

16. Mignucci, J. S. and Cordero, M., 1981. La semilla de ñames. Plagas y enfermedades. SEA, Colegio de Ciencias Agricolas, Univ. P.R., Mayagüez. Bulletin 13 pp.

17. Nwankiti, A. O. and Arene, O. B., 1978. Diseases of yam in Nigeria, PANS 24: 486-94.

18. Ogundana, S. K., 1972. The control of storage soft rot of yams in Nigeria, Biodet Bull. 8 (2): $75-8$.

19. Sachs, T. and Thimann, K. V., 1967. Role of auxins and cytokinins in the release of buds from dormancy. Am. J. Bot. 54: 136-44.

20. Samborski, D. J., Forsythe, F. R. and Person, C., 1958. Metabolic changes in detached wheat leaves floated on benzimidazole and the effect of these changes on rust reaction, Can. J. Bot. 36: 591-601.

21. Skinner, C. G., Talber, F. D. and Shive, W., 1958. Effects of 6-(Substituted) purines and gibberellin on the rate of seed germination. Plant Physiol. 33: 190-94.

22. Skoog, F. and Armstrong, D. J., 1970. Cytokinins. Ann. Rev. Plant Physiol. 21: 35984.

23. Splittstoesser, W. E. and Rhodes, A. M., 1973. Protein and amino acid values of some tropical root crops. Illinois Research 15 (4): 6-7.

24. Thompson, A. K., Been, B. O. and Perkins, C., 1977. Fungicide treatments of stored yams. Tropc. AGric. Trinidad, 54: 179-83. 